\title{
Physicochemical Modification and Surface Characterization of Citrus Microcarpa Peel Wastes Nanoparticles for the Biosorption of Copper
}

\author{
Jacinto D. Torres III \\ Senior High School Department \\ Ramon Torres National High School \\ Bago City, Philippines
}

\author{
Arlyn Joy D. Olaira \\ Senior High School Department \\ Ramon Torres National High School \\ Bago City, Philippines
}

\begin{abstract}
The Philippine mining industry has been continuously contributing to water pollution by the improper discharge of toxic effluents. Pagatban River in Southern Negros is one of the outcomes of such, due to copper contamination. Major drawbacks presented by conventional treatment methods demand an alternative which uses waste materials in the process of biosorption. This study extended the development in the aforementioned area by producing competent biosorbent nanoparticles in Pristine (PB), Alkali (NaOH) modified $(\mathrm{AB})$, and Carbonized Forms (CB) from Calamansi (Citrus microcarpa) peels for Copper removal. Biosorbents were prepared by drying, grinding, sieving, and modifying the peels. Assessment by batch biosorption followed $0.5 \mathrm{~g}: 50 \mathrm{ml}$ biosorbent-to-water ratio in 60 mins of agitation; Water samples were then analyzed using Flame Atomic Absorption Spectroscopy and a pH meter. Both in biosorption (\%) and $\mathrm{pH}$, all biosorbents were significantly different: $\mathrm{AB}$ showed the best results with means of $95.70 \%$ and 6.51 , respectively, followed by PB $(78.57 \%, 4.41)$ and CB $(76.42 \%, 5.77)$. The presence of carboxylic acid and carboxylate functional groups and the successful modification of the biosorbents were confirmed by Fourier Transform Infrared Spectroscopy. Field Emission - Scanning Electron Microscopy established the heterogeneous morphologies of quasi-spherical nanoparticles with mean sizes of $65.30 \mathrm{~nm}, 52.09 \mathrm{~nm}$, and $63.46 \mathrm{~nm}$ for $\mathrm{PB}, \mathrm{AB}$, and $\mathrm{CB}$ respectively. Moreover, predominant biosorption mechanisms recognized were ion exchange and chemisorption, which are potentially reinforced by their nanoparticle-size. Thus, the biosorbents, particularly AB can be utilized for the treatment of copper-bearing wastewaters and facilitate the valorization of $C$. microcarpa peel wastes.
\end{abstract}

Keywords: calamansi peels, biosorption, copper, alkali-modification, nanoparticles

\section{INTRODUCTION}

The Philippines is the fifth most mineral-rich country and is home to the largest copper-gold deposit in the world. With about 40 metallic mines and 62 non-metallic mines operating as of September 2016 [1].

Mining industry generates wastes, primarily during mineral extraction, beneficiation, and processing [2]. Tailings, in particular, are byproducts left over from mining and extracting resources which may include finely ground rock particles, extraction chemicals and water with high concentrations of heavy metals [3].

Mining companies in the country have long been violating its environmental regulations which caused environmental consequences [4]. In the past, as a result of irresponsible actions of a copper mining company, Pagatban River in Southern Negros experienced a devastating long-term fish-kill. It was caused by effluents that were dumped straightly into the river which lead to its deterioration, with heavy metal (copper and zinc) levels in water beyond the standard limits [5]. After three decades of no-mining activities, chemical analyses by the group of [6] confirmed that heavy metal contamination still persists in its bottom sediments. Elevated concentrations of heavy metals were also found in rivers and water bodies in Iloilo, Metro Cebu, Benguet and Manila with potential anthropogenic origins, in which some were found to be accumulating in the tissues of native aquatic organisms [7, $8-$ 10]. Thus, posing an environmental threat.

Copper $(\mathrm{Cu})$ is a vital component of human biochemistry but, is a potentially dangerous toxin. It is linked to various neurodegenerative diseases (such as Parkinson's disease, Alzheimer's disease, etc.) as a factor that accelerates the aggregation of their associated toxic proteins [11]. Aquatic ecosystems are also affected by $\mathrm{Cu}$ directly by impairing the olfaction (sense of smell) ability of fishes [12], by reducing algal growth, thus affecting the biota's food chain ([13] as cited by [12]), and by adversely affecting the survival, growth, reproduction, biochemical functions and even cause the mortality of aquatic organisms [14].

According to [15], Conventional technologies (coagulation, oxidation, ion exchange, etc.) that are used to remove heavy metals from water have major drawbacks such as poor costeffectiveness, high toxic sludge production, and other technical constraints. This necessitates a cost-effective and eco-friendly water treatment methods. Presenting a solution is a promising biotechnology for pollutant removal and recovery termed "Biosorption". It is a physicochemical method in which pollutants are removed by biological materials from aqueous solution. It became popular because of its efficiency, simplicity, and availability of biological materials [16].

Multiple studies have assessed different pectin-rich biomass as biosorbents where they exhibited high removal efficiency [17, $18-19]$. Citrus peels and pectin were found to be containing carboxylic functional groups that enable their biosorption capabilities in the removal of metal ions [20]. In particular, Citrus microcarpa locally known as Calamansi is a hybrid plant cultivated in Southeast-Asia [21]. It is a major fruit crop of the Philippines with 28.03 thousand metric tons of produce from October to December of 2017 only, as reported by the 
Philippine Statistic Authority (PSA) [22]. Hence, the largescale consumption of calamansi mostly in juice processing, food preparation, and cosmetics, results in the abundance of solid wastes which are the discarded peels. The peels were found to be high in pectin just like those of other fruits [23] making it an auspicious candidate as biosorbent material.

The new discoveries of the types of metal-binding biomass will potentially introduce very competitive and cost-effective biosorbent products. These materials can function as a basis for a novel technology for metal removal and retrieval. However, biosorption is still in progress and requires further scientific understanding with the aid of chemistry and engineering disciplines [24]. Recently, nano-sized biosorbents are also being studied due to their high surface area [25].

This study expanded the advancement in the area of biosorption by producing competent biosorbents (Pristine, Alkalimodified, \& Carbonized Forms) in nanoparticle-size from Citrus microcarpa peels using various procedures. In addition, this work aimed to characterize the biosorbents instrumentally using Attenuated Total Reflectance - Fourier Transform Infrared Spectroscopy (ATR-FTIR) and Field Emission Scanning Electron Microscopy (FESEM) in order to determine the surface functional groups, particle size and distribution, and surface morphology of the biosorbents. It aimed to evaluate the copper concentration and the $\mathrm{pH}$ of the copper contaminated water before and after the application of the biosorbents and also their biosorption percentage (\%), and it aimed to statistically investigate if there is a significant difference among the aforementioned variables in terms of the parameters considered. All of these are directed to the elucidation of the biosorptive mechanisms of the biosorbents on the removal of copper from water.

The results of this study could act as a foundation in the development of new materials in Philippine water treatment technology for metal removal and prospectively their recovery, leading to their real-world application in industrial and mining sectors. Thus, it could significantly mitigate the impending environmental and health hazards of heavy metal exposures, particularly of copper.

\section{MATERIALS AND METHODS 2.1 Research Design}

This study used descriptive research method in defining the physical and chemical characteristic of the prepared pristine, alkali modified and carbonized biosorbents with the use of instrumental analyses (ATR-FTIR and FESEM) in terms of their surface functional groups, particle size and distribution, and surface morphology. Whereas, experimental research method was used in order to assess and compare the prepared biosorbents in terms of their biosorption percentage (\%) and, the $\mathrm{pH}$ and Copper concentration of the simulated copper contaminated water after their application.

A Pretest-Posttest Control Group Design was followed in the study. The concentration of the copper, $\mathrm{pH}$ were analyzed before and after the application of the biosorbents. The data gathered from the copper concentrations were needed for the calculation of the biosorption percentage (\%). The experiment has three (3) replications for every biosorbent assessed a total of nine (9) experimental units and three (3) control units for the pretest values of the water parameters.

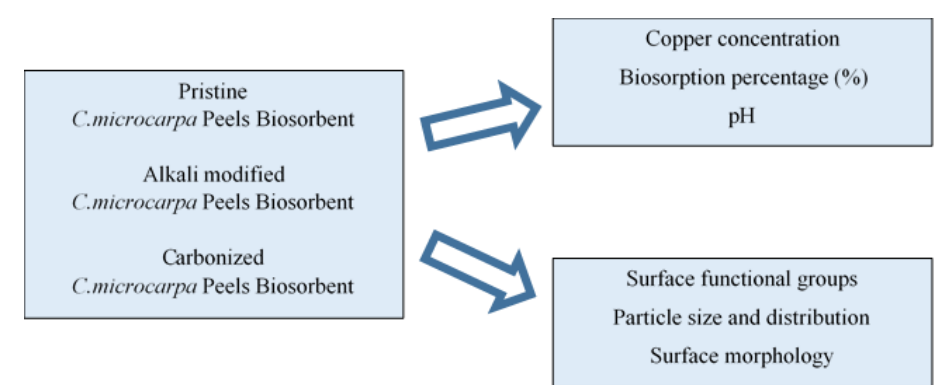

Figure 1. The relationship between the independent and dependent variables in biosorbents' assessment and characterization

*Control (Pretest) value was also be determined in the biosorption experiment

\subsection{Location and Duration of the Study}

Waste C. microcarpa peels were collected from a food establishment located at General Luna St., Brgy. Balingasag, Bago City, Negros Occidental, and samples were verified at the Bureau of Plant Industry's National Plant Quarantine Services Division, Station 15 - Port of Bacolod in Brgy. 39, Bacolod City.

The preparation of the biosorbents and water analyses for the biosorption of copper were conducted in the Sugar Regulatory Administration - Bacolod under the Research, Development and Extension Department's Agro-based Materials Laboratory it is located at Araneta St., Singcang, Bacolod City, Philippines.

Further characterizations of the $C$. microcapa biosorbents using Field Emission Scanning Electron Microscope (FE-SEM) and Attenuated Total Reflectance - Fourier Transform Infrared Spectroscopy (ATR-FTIR) were conducted at the Industrial Technology Development Institute (ITDI) of the Department of Science and Technology (DOST) located at General Santos Ave., Bicutan, Taguig City, Philippines under the Advanced Device and Material Testing Laboratory (ADMATEL) and the Standards and Testing Division.

Gathering of the materials started on July 23, 2018, while the last data gathering was on September 03, 2018.

\subsection{Collection and Authentication of Citrus microcarpa Peel Wastes}

One (1) kilogram of waste calamansi peels was collected from a local food establishment in Bago City. The fruit and peel samples were sent to the Bureau of Plant Industry (BPI), National Plant Quarantine Services Division, Bacolod City for the verification of the plant's scientific name.

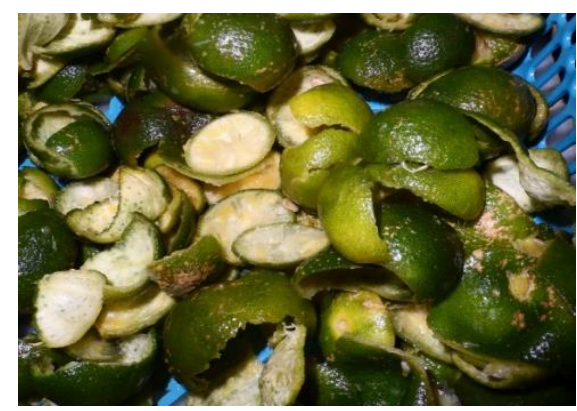

Figure 2. Cleaned Citrus microcarpa peels

\subsection{Preparation of Biosorbents}




\subsubsection{Pristine C. microcarpa Peels Biosorbent (PB)}

The collected $C$. microcarpa peels were separated from the other parts (seeds \& endocarp) and were washed thoroughly using distilled water to remove unwanted materials. Afterwards, it was dripped and air dried for fifteen (15) minutes. The cleaned calamansi peels obtained had a fresh weight of $800 \mathrm{~g}$. The peels were dried using a Laboratory drying oven in $100^{\circ} \mathrm{C}$ for 12 hours to remove moisture and water. Then $200 \mathrm{~g}$ of the dried materials were grounded using a grinder and sieved using a U.S. Standard Sieve No. 40. The biosorbent was then stored in a clean and closed container labeled as Pristine Biosorbent (PB).

\subsubsection{Alkali-Modified C. microcarpa Peels Biosorbent (AB)}

Alkali Modification was based on the treatment methods presented by [26] and [27]. The $0.05 \mathrm{M}$ aqueous solution of Sodium hydroxide $(\mathrm{NaOH})$ was prepared by dissolving two (2) grams of $\mathrm{NaOH}$ pellets with one (1) liter of distilled water thru the aid of a magnetic stirrer.

Ten (10) grams of Pristine Biosorbent was treated by immersion with $0.05 \mathrm{M}$ aqueous solution of Sodium hydroxide $(\mathrm{NaOH})$ for three (3) hours at room temperature. Then, it was washed thoroughly with demineralized/distilled water until neutral $\mathrm{pH}$ (7) via decantation and filtration procedures, then dried in an oven at $70^{\circ} \mathrm{C}$ for $12 \mathrm{~h}$ and subsequently grinded. The biosorbent was sieved using a U.S. Standard Sieve No. 40 and stored in a clean and closed container. It was labeled as Alkali Modified Biosorbent (AB).

\subsubsection{Carbonized C. microcarpa Peels Biosorbent (CB)}

To facilitate carbonization the Pristine Biosorbent was contained in a closed ceramic container with a small opening on the top. The vessel was then subjected to heat at 60 minutes and washed using distilled water. Then, it was sieved using a U.S. Standard Sieve No. 40. It was then stored in a clean and closed container to avoid contamination with moisture, unnecessary moisture can cause the degradation of the material. It was labeled as Carbonized Biosorbent (CB).

\subsection{Spectroscopic and Microscopic Surface Characterization of Biosorbents}

\subsubsection{Attenuated Total Reflectance - Fourier Transform Infrared Spectroscopy}

The different pristine and modified biosorbents were sent to the Department of Science and Technology-Industrial Technology Development Institute (DOST-ITDI) at Gen. Santos Ave., Bicutan, Taguig, Metro Manila 1631. Where the Biosorbents were analyzed via Attenuated Total Reflectance - Fourier Transform Infrared Spectroscopy also known as ATR-FTIR in the range of $4,000-400 \mathrm{~cm}^{-1}$ using an ABB MB3000, in order to determine the chemical and functional groups present in the surface of the materials that would help in elucidating their biosorption mechanisms.

\subsubsection{Field Emission - Scanning Electron Microscopy}

The C. microcarpa peel biosorbents were subjected to Field Emission - Scanning Electron Microscope (FE-SEM) to define its surface morphology, particle size and particle size distribution with the aid of Advanced Device and Materials Testing Laboratory (ADMATEL) of the Department of Science and Technology-Industrial Technology Development Institute (DOST-ITDI) at Gen. Santos Ave., Bicutan, Taguig, Metro Manila 1631.
Prior to the analysis, the particles were grounded using a carbon tape in relative humidity of $50 \pm 10 \%$ and Room temperature between $+20^{\circ} \mathrm{C}$ and $+25^{\circ} \mathrm{C}$. For the imaging, the instrument used was Dual Beam Helios Nanolab 600i. The samples were loaded and analyzed based on the instrument's user operation manual. The FESEM imaging was conducted using the following parameters: FESEM Accelerating voltage of 2.0 to $5.0 \mathrm{kV}$ Secondary Electron - Through Len Detector (SE-TLD) and Beam Current of $86 \mathrm{pA}$.

To analyze particle size distribution, SE-TLD mode images (preferably with evident black-and-white-contrast of nanoparticles) for each sample were obtained. The nanoparticle size (image) were then analyzed using ImageJ software following the Feret diameter method. Data analysis was done by analyzing the frequency distribution of nanoparticles, in $\mathrm{nm}$ (using histogram). These analyses would help in expounding the behavior of the materials as biosorbents.

\subsection{Biosorption of Copper using C. microcarpa Peel Biosorbents}

\subsubsection{Preparation of Simulated Copper Contaminated Wastewater}

$30 \mathrm{ppm}$ copper solution was prepared by dissolving Copper sulfate pentahydrate crystals $(\mathrm{CuSO} 4 \cdot 5 \mathrm{H} 2 \mathrm{O})$ in distilled water with the help of a magnetic stirrer and labeled as Simulated Copper Wastewater.

\subsubsection{Assessment of the Biosorbents using Batch Biosorption Experiment}

Biosorption of copper were assessed using a batch experiment were the biosorbents were suspended in the water in a certain period of time. Methods are based on the work of [28].

A constant amount of $0.5 \mathrm{~g}$ of the biosorbents was contacted with $50 \mathrm{ml}$ of simulated copper contaminated wastewater. Nine (9) plastic laboratory bottles were used to contain the materials for the reaction, and they were labeled according to the biosorbent used. Pristine, Alkali-Modified, and Carbonized Calamansi Biosorbent were placed in separate plastic bottles having three replicates in each treatment.

The plastic laboratory bottles labeled as PB contained the Pristine Calamansi biosorbent, while bottles labeled as AB were for the Alkali Modified Calamansi biosorbent and the bottles labeled CB for the Carbonized Calamansi biosorbent. The plastic containers were shaken for one (1) hour using a reciprocal shaker.

Subsequently, the samples were filtered separately using Whatman no. 42 filter paper in a glass funnel with the help of a funnel stand. Then, the filtrates were dripped inside the labeled volumetric flasks. The samples were then subjected to analysis.

\subsection{Pretest and Posttest Analysis of Water Samples}

\subsubsection{Test for the Determination of $\mathrm{pH}$}

Sartorius PB-11 was used to measure the $\mathrm{pH}$ level of the water samples. Before the analysis the device was calibrated using standard buffer solutions. The device read and stabilized the result. The electrode was rinsed with distilled water and was blotted dry. The electrode was then placed into a container containing a sample of $25 \mathrm{~mL}$ water sample and measured the sample's $\mathrm{pH}$. 


\subsubsection{Test for the Determination of Copper concentration}

Standard solutions containing a varying concentration of copper (1ppm, 2ppm, 3ppm, \& 4ppm) were prepared for the air-acetylene Flame Atomic Absorption Spectrophotometer (FAAS). The spectrophotometer was turned on and was allowed to warm-up for ten (10) minutes. Afterwards, the standard solutions were read.

The pretest and posttest water samples were analyzed for copper concentration using Flame Atomic Absorption Spectrophotometer (FAAS) with air-acetylene.

\subsection{Risk Assessment and Safety Precautions}

Experiments were done under the supervision of a Licensed Chemist/Sr. Research Specialist. Proper laboratory attire (Lab gown, mask, rubber gloves etc.) were followed throughout the experimentation especially in handling chemicals to ensure the safety of the researcher. Various emergency apparatus were also stationed all throughout the laboratory such as Emergency eyewash and shower, First aid kit and Fire extinguisher.

\subsection{Proper Disposal}

The water samples were disposed of properly at the disposal unit of the laboratory with the guidance of the laboratory chemist. The leftover stock solutions were kept and stored for future use. The used biosorbents were stored in zip lock bags for further study.

\subsection{Data Gathering and Analysis}

The concentration or the number of copper ions in the water were expressed in part per million (ppm). The concentration of copper and $\mathrm{pH}$ of the water samples were measured before and after the biosorption experiments. The concentration of the copper ions in the contaminated water was analyzed using a Flame Atomic Absorption Spectrophotometer (FAAS).

The Data were subjected for the calculation to determine the biosorption percentage (\%) to the equation:

\section{Biosorption $=\left(C_{i}-C_{f}\right) / C_{i} \times 100 \%$}

Where $C_{i}$ is the initial concentration and $C_{f}$ is the final concentration of Copper ions (ppm) in the contaminated water. Based on the equation used by [29].

For the ATR-FTIR Spectra, Correlation/Assignment Charts were used in order to assign the important functional groups of the biosorbents.

\subsection{Statistical Data Analysis}

Data gathered were analyzed using the IBM Statistical Package for Social Science (SPSS) Software 22 using the following tools:

Mean - used as a descriptive tool to establish the average adsorption efficiency and capacity of the treatments.

Standard Deviation - The standard deviation was used as a descriptive tool to find out how far the values are from the mean (Represented by error bars).

One-way Analysis of Variance (ANOVA) at $\alpha=0.05$ - was used as an inferential tool to determine if there was a significant difference among the water samples before biosorption (Pretest) and after biosorption using the prepared biosorbents (Pristine, Alkali-modified, and Carbonized Biosorbents) in terms of their copper concentration and $\mathrm{pH}$, and to determine if there are significant differences among the (\%) biosorption of the biosorbents.

Duncan's Multiple Range Test (DMRT) - used as an inferential tool to determine which of the means are equal and which are significantly different.

\section{RESULTS}

\subsection{Characterization of the $C$. microcarpa Peel Biosorbents}

\subsubsection{Fourier Transform Infrared Spectroscopy}

Figure 3. ATR-FTIR Spectrum of Pristine Calamansi Biosorbent

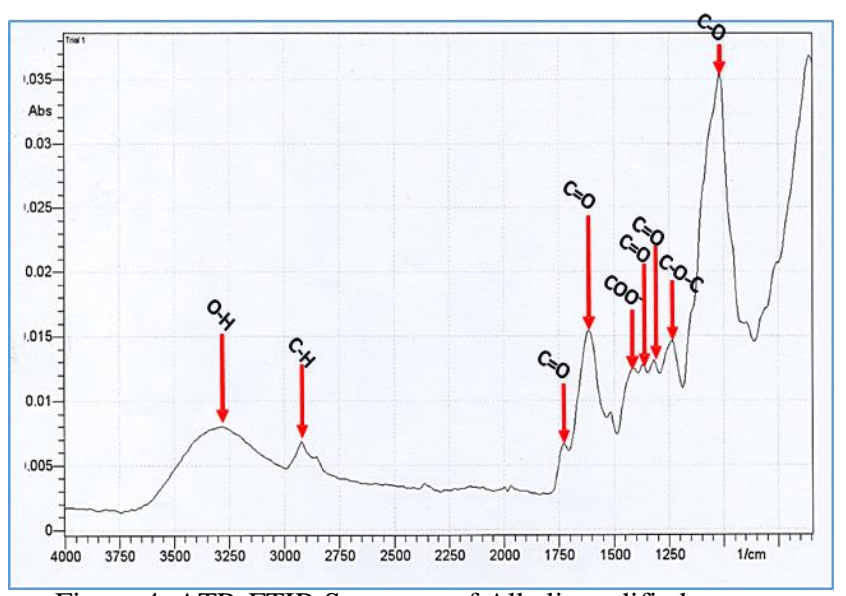

Figure 4. ATR-FTIR Spectrum of Alkali-modified Calamansi Biosorbent

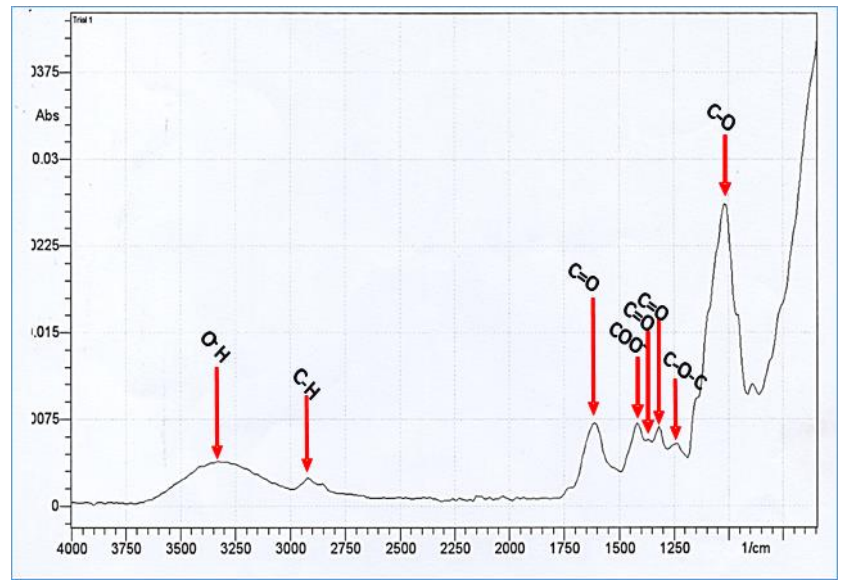




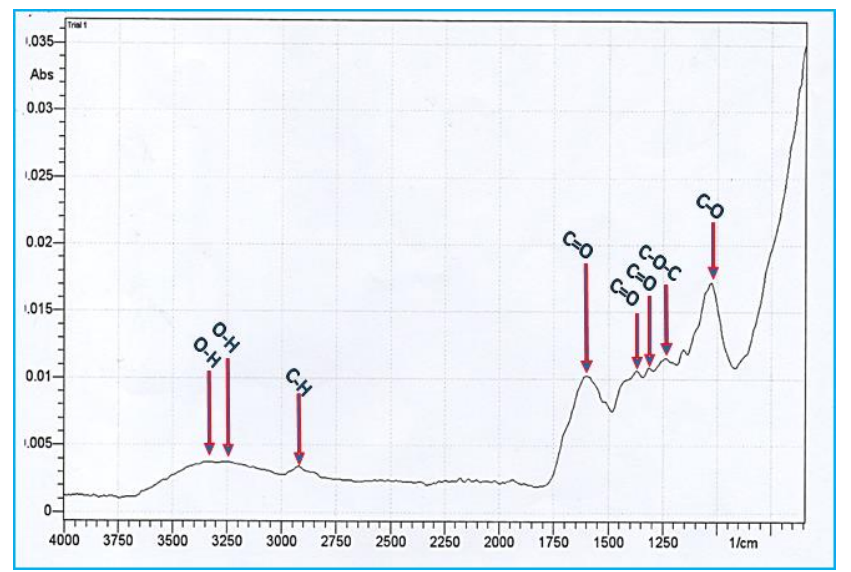

Figure 5. ATR-FTIR Spectrum of Carbonized Calamansi Biosorbent

Table 1. Summary of Important Functional groups of the $C$. microcarpa peel Biosorbent Nanoparticles

\begin{tabular}{|l|c|c|c|}
\hline \multirow{2}{*}{$\begin{array}{c}\text { *Functional } \\
\text { Group }\end{array}$} & \multicolumn{3}{|c|}{ Wavenumber, cm ${ }^{-1}$} \\
\cline { 2 - 4 } & PB & AB & CB \\
\hline O-H Stretching & 3286 & 3333 & 3325, \\
\hline C-H Stretching & 2924 & 2924 & 2924 \\
\hline C=O Stretching & 1728 & - & - \\
(ester) & & 13248 \\
\hline C=O (Carboxylate) & 1612 & 1612 & 1597 \\
\hline COO- (Pectin) & 1412 & 1420 & - \\
\hline C=O (Carboxylate) & 1366, & 1373, & 1373, \\
& 1319 & 1319 & 1311 \\
\hline C-O (pectin) & 1018 & 1018 & 1018 \\
\hline
\end{tabular}

*Assigned with reference to $[30,31$ - 32]

Different Functional groups of the biosorbent were identified using Fourier Transform Infrared Spectroscopy - Attenuated Total Reflectance. The spectra of the biosorbents indicate successful modification of the C. microcarpa peels particles.

FTIR Spectroscopy is a technique based on the determination of the interaction between an IR radiation and a sample that can be solid, liquid or gaseous. It measures the frequencies at which the sample absorbs, and also the intensities of these absorptions. The frequencies are helpful for the identification of the sample's chemical make-up due to the fact that chemical functional groups are responsible for the absorption of radiation at different frequencies. It can be used for characterization of biomaterials used in depolluting processes, but also to characterize materials obtained after chemical modification. Particularly, ATR-FTIR is a non-destructive, reliable and robust technique in the analysis of wide-array of samples [33].

Hydroxyl $(\mathrm{O}-\mathrm{H})$ stretching was observed in wavenumbers of $3286 \mathrm{~cm}^{-1}$ for $\mathrm{PB}, 3333 \mathrm{~cm}^{-1}$ for $\mathrm{AB}$, and $3325 \mathrm{~cm}^{-1}$ and 3248 $\mathrm{cm}^{-1}$ for CB. C-H stretching was detected at $2924 \mathrm{~cm}^{-1}$ for all of the biosorbents. Stretching of Carbonyl $(\mathrm{C}=\mathrm{O})$ functional group of ester was observed in $\mathrm{PB}$ at $1728 \mathrm{~cm}^{-1}$ but absent in $\mathrm{AB}$ and $\mathrm{CB}$. For the carbonyl $(\mathrm{C}=\mathrm{O})$ functional group of carboxylate/carboxylic acid salts, peaks were found at 1612, 1612 , and $1597 \mathrm{~cm}^{-1}$ for $\mathrm{PB}, \mathrm{AB}$, and $\mathrm{CB}$, respectively. Carboxylate $\left(\mathrm{COO}^{-}\right)$of pectin were observed at $1412 \mathrm{~cm}^{-1}$ and $1420 \mathrm{~cm}^{-1}$ for $\mathrm{PB}$ and $\mathrm{AB}$, respectively. Again, Carbonyl $(\mathrm{C}=\mathrm{O})$ functional group of carboxylate were detected at 1366 and 1319 $\mathrm{cm}^{-1}$ for $\mathrm{PB}, 1373$ and $1319 \mathrm{~cm}^{-1}$ for $\mathrm{AB}$, and 1373 and 1311 $\mathrm{cm}^{-1}$ for CB. C-O-C functional group was found at 1234, 1242, and $1234 \mathrm{~cm}^{-1}$ for $\mathrm{PB}, \mathrm{AB}$, and $\mathrm{CB}$, respectively. $\mathrm{C}-\mathrm{O}$ of pectin was observed at $1018 \mathrm{~cm}^{-1}$ for all of the biosorbents.

\subsubsection{Field Emission - Scanning Electron Microscopy}
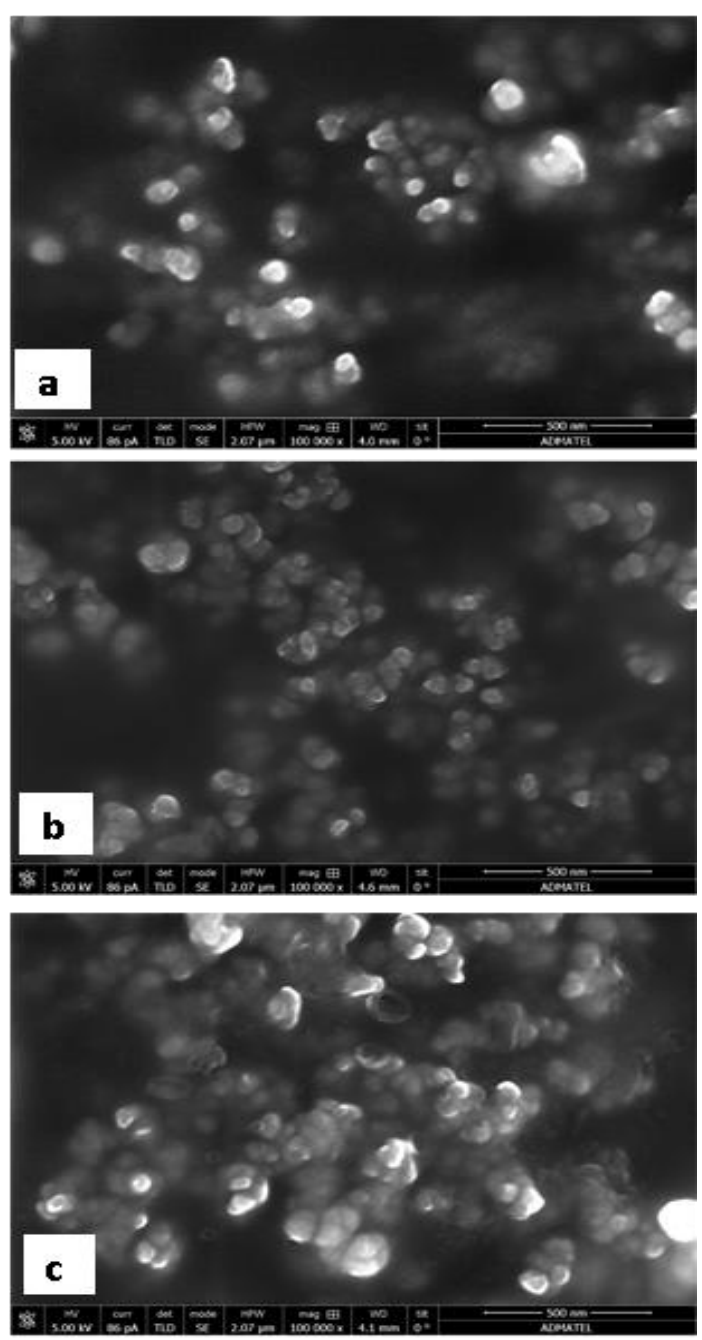

Figure 6. Field Emission - Scanning Electron Micrographs of

(a) Pristine, (b) Alkali-modified, and (c) Carbonized C. microcarpa peels Biosorbent nanoparticles taken at 100 000x magnifications

Greyish clustered globules as seen in the FE-SEM Micrographs (Figure 6) of the different $C$. microcarpa peels particles 
revealed that the biosorbent nanoparticles have heterogeneous, irregular and quasi-spherical morphology, it was also observed that the particles are aggregated. Furthermore, particle-size measurements (Feret's diameter method) determined sizes of the pristine (Figure 6a), alkali-modified (Figure 6b) and carbonized (Figure 6c) biosorbents nanoparticles as observed at $100000 x$ magnification, with means of $65.30 \mathrm{~nm}, 52.09 \mathrm{~nm}$, and $63.46 \mathrm{~nm}$ respectively (see Table 2 ).

Table 2. Mean Particle Size Measurement $(\mathrm{n}=20)$ for all $C$. microcarpa peel particle samples

*Particle size was measured using Feret's method in ImageJ software

\begin{tabular}{|c|c|c|c|}
\hline \multirow{2}{*}{} & \multicolumn{3}{|c|}{ Calamansi peel biosorbents' particle size* $(\mathrm{nm})$} \\
\cline { 2 - 4 } & $\mathrm{PB}$ & $\mathrm{AB}$ & $\mathrm{CB}$ \\
\hline Mean & 65.30 & 52.09 & 63.46 \\
\hline
\end{tabular}

Figure 7. Particle size distribution of all biosorbent samples using Feret diameter method

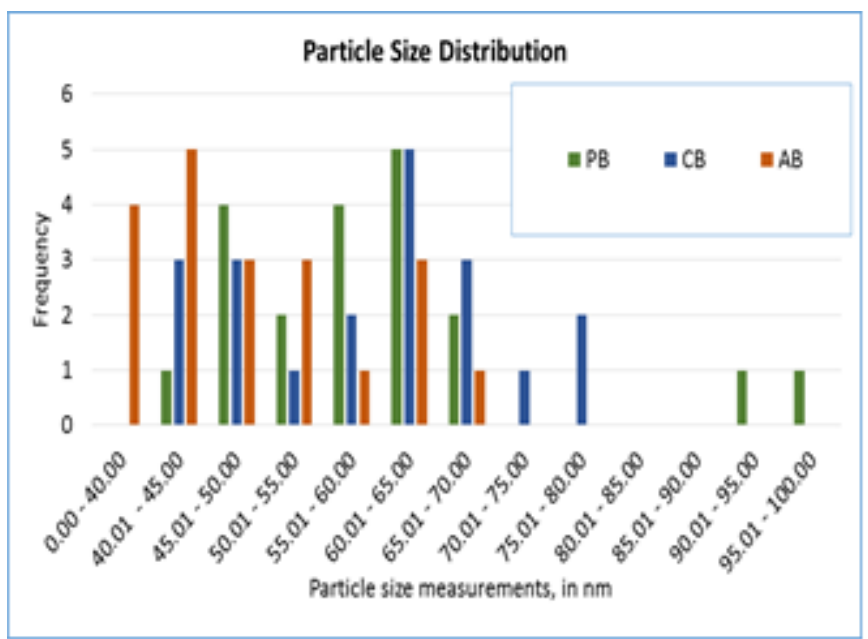

Based on the data obtained (see Table 2) all estimated sizes of the samples via the Feret Diameter Method are in the nanometer size. In terms of the particle size distribution, as shown in Figure 7, the PB and CB have frequently distributed from the range of 60.01 to $65.00 \mathrm{~nm}$ while $\mathrm{AB}$ is most frequently distributed from the range of 40.01 to $45.00 \mathrm{~nm}$. However, these results are only based on the selected measurements done on certain (specific areas) of each sample and the data obtained are only limited to 20 measurements.

\subsection{Batch Biosorption of Copper Using the C. microcarpa Peel Biosorbents}

\subsubsection{Copper concentration of water samples}

Figure 8. Mean copper concentrations of the water samples before and after the biosorption of copper using the $C$. microcarpa peel biosorbents

*Means with different superscripts $(a, b \& c)$ are significantly

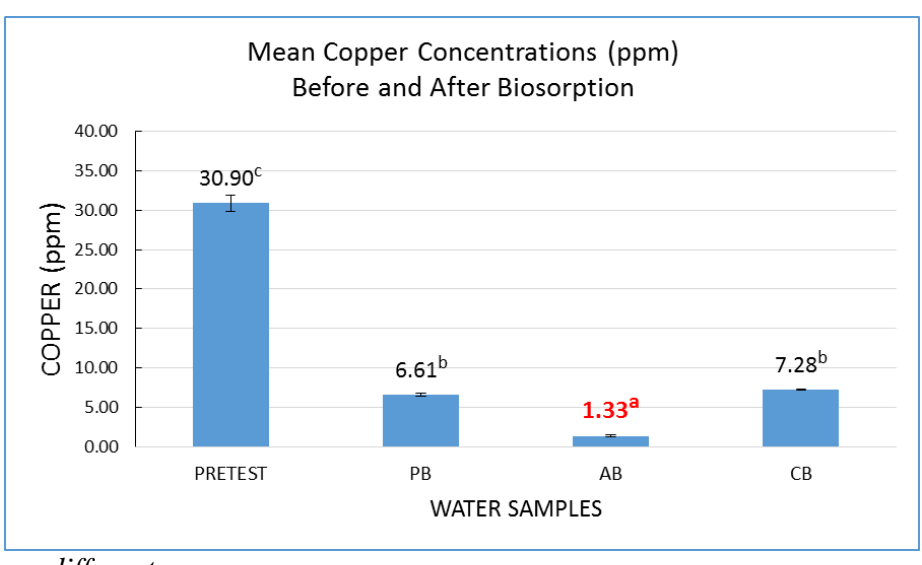

different

Table 3. One-way Analysis of Variance of the Copper Concentration (ppm) of the Water Samples

\begin{tabular}{|l|c|c|c|c|c|}
\hline & $\begin{array}{c}\text { Sum of } \\
\text { Squares }\end{array}$ & Df & $\begin{array}{c}\text { Mean } \\
\text { Square }\end{array}$ & F & $\begin{array}{c}\text { Sig. } \\
\text { (p- } \\
\text { value) }\end{array}$ \\
\hline $\begin{array}{l}\text { Between } \\
\text { Groups }\end{array}$ & 1564.032 & 3 & 521. & 1769. & .000 \\
\hline $\begin{array}{l}\text { Within } \\
\text { Groups }\end{array}$ & 2.357 & 8 & .295 & & \\
\hline Total & 1566.389 & 11 & & & \\
\hline
\end{tabular}

*Further analyzed with IBM Statistical Package for Social Science (SPSS) Software 22

The simulated copper contaminated water along with the treated water samples using the different biosorbents were analyzed for copper concentration using a Flame Atomic Absorption Spectrophotometer (FAAS) with acetylene. Atomic Absorption Spectrophotometry is a technique in the quantitative analysis of chemical elements present in environmental samples by measuring the absorbed radiation by the chemical element of interest. This is done by reading the spectra produced when the sample is excited by radiation [34]. This standard method is identified by the American Standards for Testing and Materials (ASTM) under the ASTM D1688 17 which is the "Standard Test Methods for Copper in Water" [35].

The biosorption of copper using the pristine, alkali modified, and carbonized $C$. microcarpa peel biosorbents were assessed using a batch biosorption experiment where a constant mass of biosorbents $(0.5 \mathrm{~g})$ was suspended in a constant volume of the water sample $(50 \mathrm{ml})$ and shaken for one (1) hour. As seen in Figure 8 after the batch experiment the biosorbent materials were able to reduce the concentrations of copper as compared to the mean pretest (control) value of $30.9 \mathrm{ppm}(\mathrm{Cu})$ which did not undergo any treatment. 
Results of One-way Analysis of Variance (One-way ANOVA) at 0.05 alpha value level of significance as shown in Table 3 indicates that there is a significant difference among the copper concentration of the water samples treated with the biosorbents and the pretest value $(\mathrm{F}$-value $=1769.567 \&$ p-value $=0.000)$. As shown in Figure 8, Duncan's Multiple Range Test (DMRT) as Post hoc (alpha value $=0.05$ ) as denoted by the superscripts revealed that there is no significant difference between $\mathrm{PB}$ and $\mathrm{CB}$ in terms of the copper concentration but they are significantly different from the Pretest and AB. The lowest value for copper ( $\mathrm{ppm}$ ) was exhibited by $\mathrm{AB}$ with a mean of $1.33 \mathrm{ppm}$ followed by PB (6.61 ppm), CB (7.28 ppm) and Pretest (30.9 ppm).

\subsubsection{Percent (\%) Biosorption of Copper}

Figure 9. Mean (\%) Biosorption of the C. microcarpa peel biosorbents in copper biosorption

*Means with different superscripts (a, b \& c) are significantly

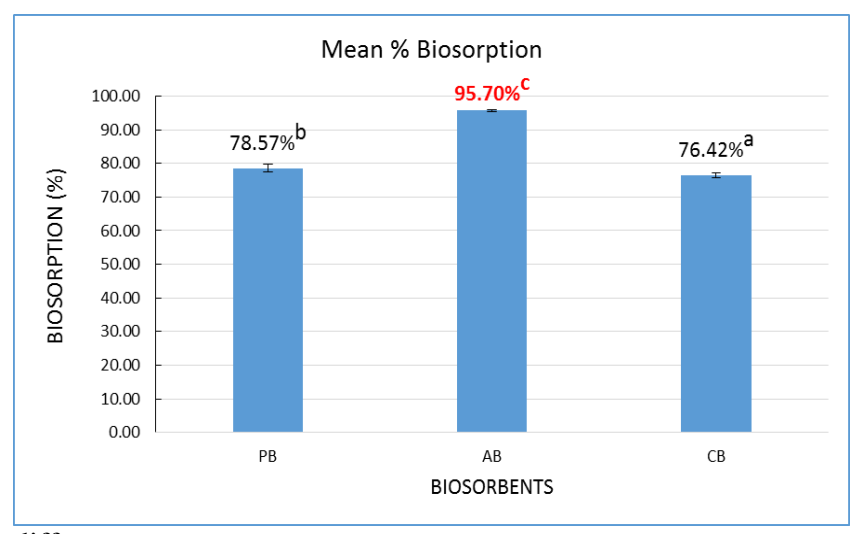

different

Table 4. One-way Analysis of Variance of the (\%) Biosorption

\begin{tabular}{|c|c|c|c|c|c|}
\hline & $\begin{array}{l}\text { Sum of } \\
\text { Squares }\end{array}$ & Df & $\begin{array}{l}\text { Mean } \\
\text { Square }\end{array}$ & $\mathbf{F}$ & $\begin{array}{c}\text { Sig. } \\
\text { (p- } \\
\text { value) }\end{array}$ \\
\hline $\begin{array}{l}\text { Between } \\
\text { Groups }\end{array}$ & 669.392 & 2 & $\begin{array}{r}334 . \\
696\end{array}$ & $\begin{array}{r}499 . \\
580\end{array}$ & .000 \\
\hline $\begin{array}{l}\text { Within } \\
\text { Groups }\end{array}$ & 4.020 & 6 & .670 & & \\
\hline Total & 673.412 & 8 & & & \\
\hline
\end{tabular}

*Further analyzed with IBM Statistical Package for Social Science (SPSS) Software 22

Percentage Biosorption was calculated by subjecting the copper concentration data to the formula by [28]: Biosorption $=\left(C_{i}-C_{f}\right) / C_{i} x \mathbf{1 0 0 \%}$, where $C_{\mathrm{i}}$ is the initial concentration and $\mathrm{C}_{\mathrm{f}}$ is the final concentration of Copper ions in the contaminated water used. The biosorption efficiency reflects the percentage of copper that was removed by the biosorbents from the water.

One-way ANOVA at 0.05 alpha value level of significance revealed that the mean percentage biosorption efficiency of the biosorbents are significantly different from each other (Fvalue $=499.580 \&$ p-value $=0.000)$ as shown in Table 4 .
As shown in Figure 9, DMRT, as denoted by the superscripts, showed that Alkali modified C.microcarpa biosorbent exhibited the highest percentage biosorption with $95.70 \%$, followed by $\mathrm{PB}$ with $78.57 \%$ and $\mathrm{CB}$ with $76.42 \%$. It was revealed that modification of the biosorbent using an alkali solution (0.05 M NaOH) enhanced its (\%) copper biosorption which indicates that it is a better biosorbent compared to the raw form. But, the modification of the biosorbent thru carbonization showed a negative effect on its ability to remove copper from water.

\subsection{3 $\mathrm{pH}$ level of water samples}

Figure 10. Mean $\mathrm{pH}$ value of water samples before and after the biosorption of Copper using C. microcarpa peel biosorbents

*Means with different superscripts ( $a, b$ \& c) are significantly different

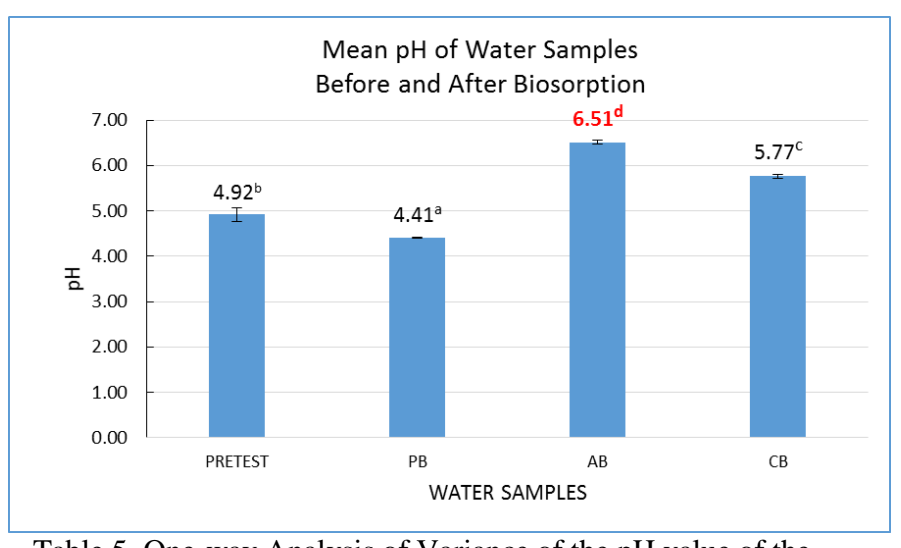

Table 5. One-way Analysis of Variance of the $\mathrm{pH}$ value of the Water Samples

\begin{tabular}{|l|r|r|r|r|r|}
\hline & $\begin{array}{c}\text { Sum of } \\
\text { Squares }\end{array}$ & Df & $\begin{array}{c}\text { Mean } \\
\text { Square }\end{array}$ & F & $\begin{array}{r}\text { Sig. } \\
\text { (p- } \\
\text { value) }\end{array}$ \\
\hline $\begin{array}{l}\text { Between } \\
\text { Groups }\end{array}$ & 7.753 & 3 & 2.584 & $\begin{array}{r}399 . \\
654\end{array}$ & \begin{tabular}{l}
.000 \\
\hline Within \\
Groups
\end{tabular} \\
\hline Total & 7.052 & 8 & .006 & & \\
\hline
\end{tabular}

*Further analyzed with IBM Statistical Package for Social Science (SPSS) Software 22

Figure 10 shows that there is a change in the $\mathrm{pH}$ values of the water samples after the biosorption of copper. One-way ANOVA revealed that the $\mathrm{pH}$ values of the water sample are significantly different with each other with F-value of 399.654 and $\mathrm{p}$-value of 0.000 as shown in Table 5. DMRT, as represented by superscripts (Figure 10), showed that $\mathrm{AB}$ displayed the highest $\mathrm{pH}$ value of 6.51 , followed by $\mathrm{CB}$ with 5.77, Pretest with 4.92, and PB with 4.41.

Using only the simulated copper contaminated water in a batch biosorption experiment, only the mean $\mathrm{pH}$ of the water samples after the biosorption of copper using the Alkali-modified Biosorbent $(\mathrm{AB})$ was able to reach the standard range for $\mathrm{pH}$ of Class A effluents as mandated by the Department of 
Environment and Natural Resources (DENR Administrative Order No. 2016-08) [36]. In contrast to the results shown in the \% Biosorption, $\mathrm{CB}$ exhibited better values in terms of $\mathrm{pH}$ compared to the pristine form.

\section{DISCUSSIONS \\ 4.1 Characterization of Surface Functional Groups ATR-FTIR}

The presence of functional groups on the surface of the biosorbent particles was confirmed using Attenuated Total Reflectance - Fourier Transform Infrared Spectroscopy (ATRFTIR). Hydroxyl functional group and carbonyl functional groups of carboxylic acid, carboxylates, and esters were found on the biosorbents that could have contributed in the binding of copper ions from water. The shifting of the peaks of carbonyl (from $1412 \mathrm{~cm}^{-1}$ to $1420 \mathrm{~cm}^{-1}$ ) and of carboxylates (from 1366 $\mathrm{cm}^{-1}$ to $1373 \mathrm{~cm}^{-1}$ ) after the modification of the biosorbent particularly after alkali treatment indicates interaction of the biomass to the sodium ions. Also, the peak for ester at $1728 \mathrm{~cm}^{-}$ ${ }^{1}$ disappeared after the alkali modification and carbonization, as mentioned by [26] alkali treatment facilitates the conversion of esters present in the pristine biosorbent into carboxylic acid in the process of base-promoted ester hydrolysis/saponification, which is then converted to carboxylate [37]. On the other hand, peak at $1412 \mathrm{~cm}^{-1}$ for carboxylate disappeared only after carbonization. The alteration or/and elimination of some of the functional groups, hydroxyl groups, in particular, may have caused the variation in the water samples' $\mathrm{pH}$ values, where the modified biosorbents showed lower acidity compared to the output of the raw form.

\subsection{Characterization of Surface Morphology and Particle Size and Distribution Using FESEM}

As established by Field Emission Scanning Electron Microscopy (FESEM), biosorbent nanoparticles of $C$. microcarpa peel wastes were successfully produced and modified using Alkali modification (via $\mathrm{NaOH}$ ) and Carbonization. Nanoparticles of the biosorbents were observed to have heterogeneous and quasi-spherical morphology. It is also evident in the micrographs that the particles are agglomerated in nature. Results of the ImageJ Analysis using Feret's method showed that the nanoparticles vary in size. Due to the modifications, the size of the particles was reduced and the particle size distributions were narrowed down as compared to the raw/pristine form. Specifically, alkali treatment with $\mathrm{NaOH}$ affects the lignin and holocellulose compounds on the surface of the nanoparticles resulting in a decrease in the particle size [38 - 39].

The excellent biosorption abilities of the nanoparticles may be attributed to their functional groups and their nano-size. The nanometer size of the biosorbent, even when aggregated, enhances the materials physical and chemical properties resulting in higher removal activity [40]. The smaller the sizes of the nanoparticles the higher is their surface area, which means that the material reacts better compared to materials in bulk-sizes.

\subsection{Assessment of Biosorption of Copper Using the $C$. microcarpa Peel Biosorbents in Batch Biosorption Experiment}

The usage of fruit peels as biosorbent is gaining attention due to their functionalities. [20] suggested that orange peels can be a cheap and effective material for the treatment of metal ions in water. The study of [41] showed that unripe calamansi peels can remove Congo red as evaluated using batch adsorption studies.

All of the biosorbents ( $\mathrm{PB}, \mathrm{AB} \& \mathrm{CB}$ ) exhibited high biosorption percentage (\%), as assessed using the batch biosorption experiment. Alkali modification using Sodium hydroxide was able to increase the (\%) biosorption of copper.

After biosorption, the $\mathrm{pH}$ value of the water changed. The increase in the $\mathrm{pH}$ of the water after the treatment using the $\mathrm{AB}$ and $\mathrm{CB}$ may signify that ion exchange mechanism is one of the causes of the metal removal involving cations $\left(\mathrm{Na}^{+}\right)$. While the $\mathrm{pH}$ decreased for $\mathrm{PB}$, which most probably because of the acidic functional groups in the raw biosorbent, particularly the principal involvement of the hydroxyl group, via the exchange of Hydrogen ions $\left(\mathrm{H}^{+}\right)$.

\section{Figure 13. Graphical illustration of the Alkali-modification of the pristine nanoparticles using Sodium hydroxide (the molecule on the upper left side).}

*Created with references to [37, 27]

Alkali-modification both significantly increased the (\%) biosorption of copper and the $\mathrm{pH}$ of the water as compared to

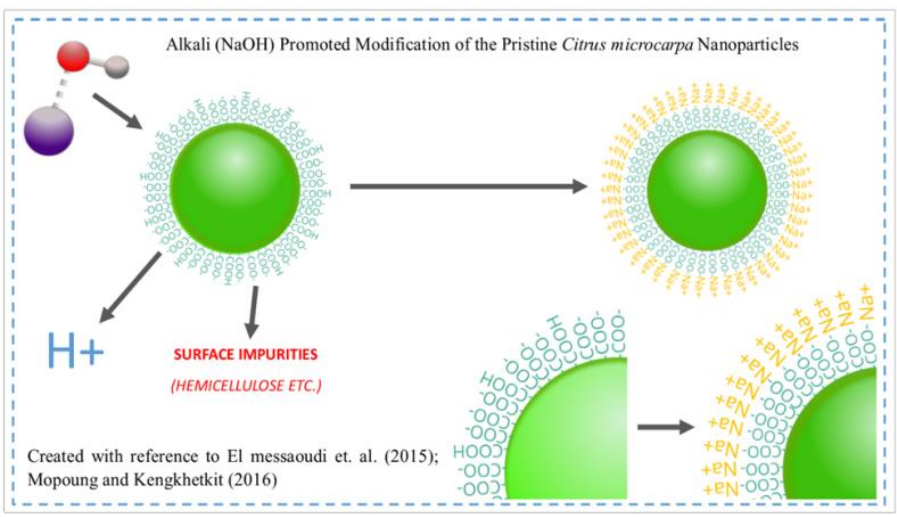

the pristine biosorbent and the carbonized biosorbent. A similar observation was obtained from the study of [26] where the alkali-treated Citrus limetta peels showed enhanced adsorption capacity in the recovery of Gallium (III). As discussed by [27], this can be explained by the removal of surface impurities present on the biosorbent particles and exposure of the active binding sites for metal adsorption after the solubilization of hemicellulose and pectin embedded in the cell walls as an effect of the treatment with Sodium hydroxide $(\mathrm{NaOH})$. Furthermore, a deprotonation of the particles should have taken place and the Sodium $\left(\mathrm{Na}^{+}\right)$cation from $\mathrm{NaOH}$ could act as the counter ion to negatively charged functional groups in the modified biosorbent. These $\mathrm{Na}^{+}$ions will be exchanged with the heavy metals ion during the sorption process, this modification also increases the cation exchange capacity of the nanoparticles [38]. Effects of the modification are further visualized as seen in Figure 13.

\subsection{Elucidation of Biosorption Mechanisms Involved in the Biosorption of Copper Using the $C$. microcarpa Biosorbents}

Biosorption mechanisms were established with the help of ATR-FTIR Spectroscopy. The carboxylic acid (RCOOH) and 
the carboxylate $\left(\mathrm{RCOO}^{-}, \mathrm{M}^{+}\right)$functional groups identified from the spectra of the C. microcarpa biosorbents can be linked to the peels' pectin content. As reported by [22], calamansi peels were able to yield high amounts of pectin ranging from 2.99 to $4.08 \%$. Pectic substances are high molecular weight polysaccharides widely spread in plants and can be found as an essential part of the primary cell wall and middle lamella of higher plants. Moreover, citrus pectin and peels were found to be possessing similar surface functional groups (especially Carboxylic acid), and this confirms that pectin is an important component in the biosorption process as elucidated in the study of [20].

Furthermore, the suggested mechanism in the removal of Congo red using calamansi peels is chemical adsorption or chemisorption involving valence forces through sharing or exchanging of electrons between adsorbate and adsorbent [41].

In general, the potential predominant mechanisms involved in the biosorption of copper (II) ions in water are ion-exchange and chelation/complexation due to carboxylic acid and carboxylate functional groups forming chelates/complexes to copper ions, with reinforcement from the physical properties (particle size and morphology) of the materials.

Figure 14. Graphical illustration of the possible interaction of the (A) Pristine or Carbonized biosorbent nanoparticles and (B) Alkali-modified biosorbent nanoparticles to the divalent copper ions.

Figure 14 above shows the simplified version of the interaction of the biosorbent nanoparticles to the copper ions in water.

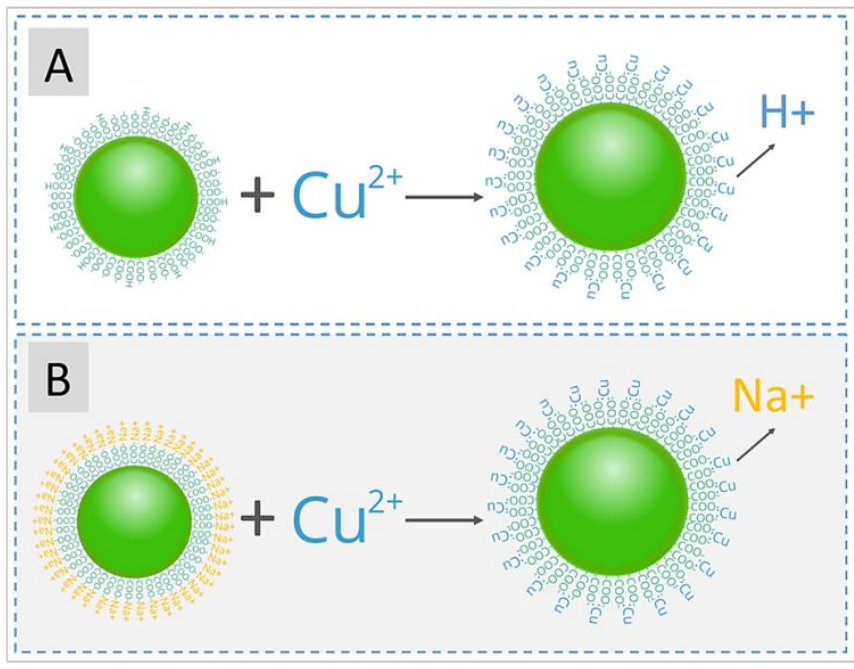

The viable reactions would be:

1. $2 \mathrm{RCOOH}+\mathrm{Cu}^{2+}(\mathrm{aq})+\mathrm{SO}_{4}{ }^{2-}(\mathrm{aq}) \rightarrow(\mathrm{RCOO})_{2} \mathrm{Cu}+\mathrm{H}_{2} \mathrm{SO}_{4}$

\section{2. $2 \mathrm{RCOO}^{-} \mathrm{Na}^{+}+\mathrm{Cu}^{2+}(\mathrm{aq})+\mathrm{SO}_{4}{ }^{2-}(\mathrm{aq}) \rightarrow(\mathrm{RCOO})_{2} \mathrm{Cu}+\mathrm{Na}_{2} \mathrm{SO}_{4}$}

Where Two (2) carboxylic acid functional groups release hydrogen ions (Reaction 1) or carboxylates releases Sodium ions (Reaction 2), which reacts with the sulfate ion, as it binds the divalent copper cation to form a complex and sulfuric acid or sodium sulfate as byproducts.

In accordance with this study the researcher would highly recommend: the analysis of the biosorbents using potentiometric titration; the application of the biosorbents in the removal of other heavy metals and organic pollutants; the analysis of the biosorbent before and after the biosorption using
Energy Dispersive X-ray Spectroscopy (EDX) and X-ray Diffraction (XRD) for further mechanistic understanding; the kinetic and isothermal investigation of the biosorbents; and the application of the biosorbents in large-scale setting for the treatment of heavy metal-bearing wastewaters.

\section{CONCLUSION}

Based on the results of the study, it is evident that the $C$. microcarpa peels in pristine, alkali-modified and carbonized form are promising biosorbents in the removal of copper from water but, the Alkali $(\mathrm{NaOH})$ modified biosorbent topped the other two. ATR-FTIR identified the existence of functional groups such as hydroxyl and carbonyl that are associated with carboxylic acids and carboxylates of pectin. The nanoparticlesize of the biosorbents were established using FESEM along with their heterogeneous and irregular morphologies, and their quasi-spherical and aggregated nature. The Biosorbents were able to decrease the concentration of copper in the water and change the $\mathrm{pH}$ of the water after the biosorption. High biosorption percentage were exhibited by the biosorbents. Moreover, there is a significant difference among the biosorbents in term of the copper concentration, $\mathrm{pH}$ and biosorption (\%) percentage, where the Alkali-modified biosorbent showed the best results. Thus, the predominant biosorption mechanisms established in this study are ion exchange mechanisms along with chelation/complexation, which are potentially reinforced by the physical properties of the biosorbents. Therefore $\mathrm{AB}$ can be utilized in water treatment systems, especially in the mining industry, for the treatment of copper-bearing wastewaters and facilitate the valorization of calamansi peel wastes.

\section{ACKNOWLEDGMENTS}

This study would not be accomplished without the presence of certain individuals that gave us their utmost support and care. First and foremost, we would like to express our gratitude to Mr. Jacinto V. Torres Jr. and Mrs. Ann Marie D. Torres, the lead researcher's parents, and the rest of the family for supporting him mentally, emotionally and financially throughout the conduct of the study. Next, To Negros Women for Tomorrow Foundation Inc. (NWTF) for funding our research under their scholarship program. To Mrs. Cynthia D. Laurente, for helping us especially on the processing and facilitation of the characterization procedures. We would also like to thank the Sugar Regulatory Administration, Bacolod City - Agro-Based Laboratory, particularly Mrs. Glenda S. Buendia and the other staffs for letting us conduct the experiments and analyses at their laboratory. Also, we are grateful to the Department of Science and Technology Industrial Technology Development Institute (ITDI) especially the staffs of Advanced Device and Materials Testing Laboratory (ADMATEL) and the Standards and Testing Division for allowing us to characterize our samples using their equipment. And last but not the least, a never-ending gratitude for our God Almighty, for guiding us and giving us the wisdom, knowledge, and passion for research.

\section{REFERENCES}

[1] Chavez, L. (April 2017). FAST FACTS: Mining in the Philippines. Rappler. Available from:

https://www.rappler.com/business/specialreport/whymining/whymining-latest-stories/11983fast-facts-mining-philippines. 
[2] Das R., and Choudhury I. (2013). "Waste Management in Mining Industry" Indian Journal of Scientific Research. 4(2). Pp. 139-142.

[3] CBC News. (August 11, 2014). Tailings ponds for mining and oilsands waste: FAQs. Accessed from http://www.cbc.ca/news/technology/tailings-pondsfor-mining-and-oilsands-waste-faqs-1.2727889.

[4] Almendral, A. (April 27, 2017). Philippines Moves to Shut Mines Accused of Polluting. The New York Times. Accessed from: https://www.nytimes.com/2017/04/27/world/asia/phili ppines-mining-environment.html.

[5] Acedo, C. E. (October 7, 2016). Heavy Metals Still Found in Pagatban River. Silliman University. Accessed from: https://su.edu.ph/2269-heavy-metalsstill-found-in-pagatban-river/.

[6] Guino-o II, R. S., Alcala, M. L. R., and Basa-Inocencio, J. E. P. (2015). Water and Bottom Sediment Quality of Pagatban River in Negros Oriental, Philippines: 30 Years after Mining Closure. Silliman Journal. 56 (1).

[7] Oquiñena-Paler, M. K. M. and Ancog, R. (2014). Copper, Lead and Zinc Concentration in Water, Sediments and Catfish (Clarias macrocephalus Gunther) from Butuanon River, Metro Cebu, Philippines. IOSR Journal of Environmental Science, Toxicology and Food Technology (IOSR-JESTFT). 8 (11) Ver. II. Pp. 49-56.

[8] Su, G. S., Martillano, K. J., Alcantara, T. P., Ragragio, E., De Jesus, J., Hallare, A., and Ramos, G. (2009). Assessing Heavy Metals in the Waters, Fish and Macroinvertebrates in Manila Bay, Philippines. Journal of Applied Sciences in Environmental Sanitation, 4 (3). pp. 187-195.

[9] Macasieb, R. Q., Tapales, B. J. M., Orozco, C. R., and Resurreccion, A. C. (2014). CHARACTERIZATION AND HEAVY METAL CONTAMINATION ASSESSMENT OF SEDIMENTS IN BUED RIVER. $11^{\text {th }}$ Engineering Research and Development for Technology Conference.

[10] Sarinas, B. G. S., Gellada, L. D., Jamolangue, E. B., Teruñez, M. R. and Flores, J. R. P. V. (2014). Assessment of Heavy Metals in Sediments of Iloilo Batiano River, Philippines. International Journal of Environmental Science and Development. 5 (6).

[11] Festa R. A., Thiele D. J. (2011). “Copper: An essential metal in biology”. Current Biology. 21 (21). Pp. R877R883. Accessed May 11, 2018 from http://www.sciencedirect.com/science/article/pii/S096 0982211010797.
[12] Solomon F. (2009). Environment and Communities: Impacts of Copper on Aquatic Ecosystems and Human Health. Norman B. Keevil Institute of Mining Engineering, University of British Columbia, Vancouver, B.C.

[13] Baldwin, D. H., J. F. Sandahl, J. S. Labenia and N.L. Scholz (2003). "Sublethal Effects of Copper on Coho Salmon: Impacts on Nonoverlapping Receptor Pathways in the Peripheral Olfactory Nervous System," Environmental Toxicology and Chemistry 22(10): 2266-2274.

[14] United States Environmental Protection Agency [USEPA]. (July 2016). Fact Sheet: Draft Estuarine/Marine Copper Aquatic Life Ambient Water Quality Criteria.

[15] Ramachandra, T. V., Ahalya, N., Kanamadi, R. D. (2005). Biosorption: Techniques and Mechanisms. CES Technical Report 110.

[16] Fomina, M., Gadd, G.M. (May 2014). "Biosorption: current perspectives on concept, definition and application.” Bioresourse Technology. 160 pp. 1-3.

[17] Husoon, Z.A., Al-Azzawi, M.N.A. and Al-Hiyaly, S.A.K. (2013). Investigation Biosorption Potential of Copper and Lead from Industrial Waste-Water Using Orange and Lemon Peels. Journal of Al-Nahrain University. 16 (2). pp 173-179.

[18] Hastuti, B., and Totiana, F. (2017). GREEN ADSORBENT OF PECTIN FROM CARROT PEEL AND ITS APPLICATION AS REMOVAL OF PB(II). Proceedings of Researchfora International Conference, Edinburgh, United Kingdom, 28th-29th October.

[19] Wong, W. W., Abbas, F. M. A., Liong, M. T. and Azhar, M. E. (2008). Modification of durian rind pectin for improved biosorbent ability. International Food Research Journal. 15(3). Pp. 363-365.

[20] Balaria, A. (2006). "Biosorption of Lead By Citrus Pectin and Peels in Aqueous Solution." Unpublished Thesis. University of Alaska Fairbanks. Fairbanks, Alaska.

[21] Lim, T. K. (May 07, 2012) "Citrus x microcarpa." Edible Medicinal And Non-Medicinal Plants. Springer, Dordrecht.4. pp 865-870.

[22] Philippine Statistics Authority (PSA). (OctoberDecember 2017). Major Fruit Crops Quarterly Bulletin. 11 (4).

[23] Normah, O., Ku Hasnah, K. A., (2000). "Pectin content of selected local fruit by-products." J. Trop. Agric. and Fd. Sc. 28 (2). pp. 195-201. 
[24] Volesky, B. (2001). Detoxification of metal-bearing effluents: biosorption for the next century. Hydrometallurgy 59. pp $203-216$.

[25] Abdel-Rahman, L. H., Abu-Dief, A. M., Abd- El Sayed, M. A., and Zikry, M. M. (2016). Nano Sized Moringa oleifera an Effective Strategy for $\mathrm{Pb}$ (II) ions Removal from Aqueous Solution. Journal of Chemistry and Materials Research. 8 (4). Pp. 8-22.

[26] Gondhalekar, S. C., and Shukla, S. R. (2014). Recovery of Ga (III) by Raw and Alkali Treated Citrus limetta Peels. International Scholarly Research Notices. Hindawi Publishing Corporation. 2014. Accessed from http://dx.doi.org/10.1155/2014/968402.

[27] Mopoung, R. and Kengkhetkit, N. (2016). Lead and Cadmium Removal Efficiency from Aqueous Solution by $\mathrm{NaOH}$ Treated Pineapple Waste. International Journal of Applied Chemistry. 12(1). pp. 23-35.

[28] Khan, S., Farooqi, A., Danish, M. I., and Zeb A. (2013). BIOSORPTION OF COPPER (II) FROM AQUEOUS SOLUTION USING CITRUS SINENSIS PEEL AND WOOD SAWDUST: UTILIZATION IN PURIFICATION OF DRINKING AND WASTE WATER. International Journal of Recent Research and Applied Studies. 16 (2). Pp. 297 - 306. http://www.arpapress.com/Volumes/Vol16Issue2/IJR RAS_16_2_18.pdf.

[29] Tamilselvan, N., Saurav, K., and Kannabiran, K. (2012). Biosorption of $\mathrm{Cr}$ (VI), Cr (III), Pb (II) and Cd (II) from Aqueous Solutions by Sargassum wightii and Caulerpa racemosa Algal Biomass. J. Ocean Univ. China (Oceanic and Coastal Sea Research).

[30] Coates, J. (2000). Interpretation of Infrared Spectra, A Practical Approach. Encyclopedia of Analytical Chemistry. R.A. Meyers (Ed.). pp. 10815-10837.

[31] Talari, A. C. S., Garcia Martinez, M. A., Movasaghi, Z., Rehman, S., and Ur Rehman, I., (2017). Advances in Fourier transform infrared (FTIR) spectroscopy of biological tissues. Applied Spectroscopy Reviews. 52:5. pp 456-506. Accessed from: https://doi.org/10.1080/05704928.2016.1230863.

[32] Lambert, J. B. (1987). Introduction to Organic Spectroscopy. New York: Macmillan Publishing.

[33] Simonescu, C. M. (2012). Application of FTIR Spectroscopy in Environmental Studies. Advanced Aspects of Spectroscopy. IntechOpen. DOI: 10.5772/48331. Available from: https://www.intechopen.com/books/advanced-aspectsof-spectroscopy/application-of-ftir-spectroscopy-inenvironmental-studies.
[34] García, R. and Báez, A. P. (2012). Atomic Absorption Spectrometry (AAS), Atomic Absorption Spectroscopy, Dr. Muhammad Akhyar Farrukh (Ed.), ISBN: 978-953-307-817-5, InTech, Available from: http://www.intechopen.com/books/atomic-absorptionspectroscopy/atomic-absorption-spectrometry-aas.

[35] ASTM D1688-17. (2017). Standard Test Methods for Copper in Water, ASTM International, West Conshohocken, PA, www.astm.org.

[36] Department of Environment and Natural Resources [DENR]. (2016) Administrative Order No. 2016 - 08.

[37] El messaoudi N., Lacherai A., El khomri M., Bentahar S., and Dbik A. (2015). Modification of lignocellulosic biomass as agricultural waste for the biosorption of basic dye from aqueous solution. J. Mater. Environ. Sci. 6 (10). Pp. 2784-2794.

[38] Martín-Lara, M. A., Blázquez, G., Ronda, A., Pérez, A., and Calero M. (2013). Development and Characterization of Biosorbents To Remove Heavy Metals from Aqueous Solutions by Chemical Treatment of Olive Stone. Industrial and Engineering Chemistry Research. $52 . \quad$ pp. 10809-10819. dx.doi.org/10.1021/ie401246c.

[39] Rungrodnimitchai, S. (2014).Rapid Preparation of Biosorbents with High Ion Exchange Capacity from Rice Straw and Bagasse for Removal of Heavy Metals. The Scientific World Journal. Hindawi Publishing Corporation. Volume 2014. pp. 1-9. http://dx.doi.org/10.1155/2014/634837.

[40] Knoll J., Pennisi N., and Russo R. (April 2012). Particle Characteristic Advantages in Adsorption Technology. Water Quality Products. Retrieved from https://www.wqpmag.com/particle-characteristicadvantages-adsorption-technology-0.

[41] Sumalapao, D. E. P., Distor, J. R., Ditan, I. D., Domingo, N. T. S., Dy, L. F., and Villarante, N. R. (2016). Biosorption Kinetic Models on the Removal of Congo red onto Unripe Calamansi (Citrus microcarpa) peels. Oriental Journal of Chemistry. 32(6). pp 28892900. 